\title{
EVALUATION OF INNOVATIVE MANAGEMENT SUCCESS CRITERIA IN HOTEL ESTABLISHMENTS: CASE STUDY IN GIRESUN-TURKEY
}

\author{
Şerif Ahmet Demirdağ ${ }^{1}$, Selçuk Korucuk ${ }^{2}$ and Çağlar Karamaşa ${ }^{3 *}$ \\ ${ }^{1}$ Giresun University, Bulancak Kadir Karabaș Vocational School, Department of \\ Tourism Management, Turkey \\ ${ }^{2}$ Giresun University, Bulancak Kadir Karabaş Vocational School, Department of \\ International Trade and Logistics, Turkey \\ ${ }^{3}$ Anadolu University, Faculty of Business, Department of Business \\ Administration,Turkey
}

Received: 21 December 2020;

Accepted: 17 April 2021;

Available online: 25 April 2021.

Original scientific paper

\begin{abstract}
The purpose of this study was to determine the success criteria for innovative management in hotel establishments that have a corporate identity in the Turkish city of Giresun as well as to find out the best hotel by ranking them based on the determined criteria. For the study, "Multi-objective Optimization by Simple Ratio Analysis (MOOSRA)" and "Evaluation Based on Distance from Average Solution (EDAS)" methods were used. The results revealed that the success criteria for innovative management are beneficial in increasing operational efficiency, performance, and customer satisfaction. The results also show that managers are well aware of the success criteria for innovative management that should be prioritized, as well as those that are likely to lead to the success of their establishments and keep them ahead of the competition. While "Presenting an Innovative Vision" was found as the most important success criteria, "Use of In-Hotel Information Sources" came out as the least important one. The hotels considered were then ranked following the identified criteria.
\end{abstract}

Key words: Innovative Management, Success Criteria, MOOSRA, EDAS, Hotels.

* Corresponding author.

E-mail addresses: $\quad$ serif.demirdag@giresun.edu.tr $\quad$ (S.A. Demirdag), selcuk.korucuk@giresun.edu.tr (S. Korucuk), ckaramasa@anadolu.edu.tr (Ç. Karamaşa) 
Evaluation of innovative management success criteria in hotel establishments: Case study...

\section{Introduction}

The concepts of organization and management date back to ancient times and cover every phase of human history. Humans, as psychological and emotional beings, find it difficult to live alone, and always feel the need for others throughout their lives. It is for this reason that people have always come together in history leading to the emergence of organizations

The need by humans to live in organized systems and the advances in technological innovations in the recent past has led globalization to occupy an important role in modern society. Globalization is enhanced by, among other factors, the increasing global mutual relationships; the increasing mobility of commodity, service, money, information and culture and people; transnational technological advancements; the consideration of knowledge as a basic production component; the commitment to knowledge-based industries; the strength of international financial markets; and the rise of multinational companies. Economic globalization can be defined as the development of economic relationships between countries occasioned by improved commodity, capital, and labor mobility as well as the condensation, and spread of mutual interactions across the world (Fischer, 2003). In order to position themselves well with regard to the competition and improve their standing in the current market or venture into a new market, companies often find themselves faced with the prospect of introducing, or incorporating into their operations innovative methods and practices (Tiftik, 2020). Innovative activities, in this context, entail the efforts to develop new technologies, products, services and production processes (Drucker, 2003). Increased innovation activities call for innovative management within the firm. The success of innovative management depends on resources (people, equipment, technology, information, etc.) and the management capacity of the organization. Strategically, innovative management is essential in drawing an innovation-friendly business model and keeping the firm on a competitive path (Berghman et al., 2013).

The economic structure brought about by the increased globalization has led to the heightening of the intensity of competition in the sectors in which the enterprises operate. In this economic structure, the enterprises need to increase their competitiveness in order to survive and this can only be effectively achieved if they start to act innovatively in ways that will reduce costs, and/or make a difference (Memiş \& Korucuk, 2019). The highlighted changes have led to a move by the management systems in enterprises from a production-orientation to individualorientation, and then to a model that incorporates both approaches. Today, the innovative management approach that is the subject of this study has started to dominate Industry 4.0 and has adopted a management style focused on both the individual and production. Emerging management styles and approaches to innovation have been found to impact different sectors differently, and this has led players in different sectors, in our case, the tourism sector which holds a major share in the GDPs of most countries, to look for ways that suit their structures. The human factor is considered the most important in the tourism sector as it is humans who produce, provide and purchase services in the sector. It is therefore imperative that businesses in the sector give special attention to the human factor to attain improved efficiency and sustainability. The first step to achieving this is to strive to satisfy their employees and adopt a management style in this direction.

Various approaches are needed to realize the aforementioned issues. One of these approaches is undoubtedly an innovative management style. Innovation plays an important role in giving businesses a competitive edge and survival in the market (Burmaoğlu \& Şeşen, 2011). According to Tucker et al. (2002), innovation is one of the 
key performance indicators as an element of cumulative business success and is the responsibility of all business units. Innovation is the process by which new ideas are transformed into results that create sustainable value through economic activity (Baporikar, 2015). However, innovation is directly related to learning and change, innovation is uncertain, it has failures as well as successful results, and is often risky and costly (Bayhan, 2004). It is widely accepted that an organization's ability to innovate is closely linked to its intellectual capital or ability to use information resources (Subramaniam \& Youndt, 2005). Innovation is an important factor that creates value and ensures sustainable growth for organizations. A study by Tether (2005) finds that the focus of innovation differs with the sector. While players in the service sector focus on organizational innovation, manufacturing enterprises focus on product and process innovations. Another study finds that innovation in the service sector is geared towards strengthening relationships with customers, increasing customer loyalty, reducing costs, and increasing market efficiency (Bolton et al., 2007).

Innovative management is yet another way through which innovation can be implemented in an organization. Hamel \& Bren (2007) defined the concept of innovative management as a structure that serves organizational purposes by greatly changing the usual organizational processes and how management is done. In other words, innovative management means that an organization manages technology, processes, and human relations in a way that supports and promotes innovation. This requires having certain strategic and organizational skills. An organization is said to have strategic skills if it has a long-term vision, the ability to identify and predict market trends, the ability to collect, process and absorb technological and economic information. And, organizational skills depend on the firm's ability to identify and manage risks, the level of collaborations between operational units, the level and quality of investment in research institutions, universities, consulting firms, customers and suppliers, and human capital (Elçi, 2007). Therefore, innovative management requires a systematic focus on many aspects.

Another key factor of innovation is the organizational culture. Organizational culture emerges and develops following changes in different situations because the key component is influenced by changes in other elements (Smith et al., 2008). Culture plays an important role in the management processes as it highly influences what managers do and how (Hamel, 2007).

Innovative management can generally be considered as an organizational practice that creates added value in organizational roles and structures (Soylu \& Göl, 2010). It aides the organization in gaining a competitive advantage, adopting a flexible structure, ensuring internal and external customer satisfaction, and taking on an agile structure while reducing their costs.

There are several success criteria for effective, efficient, and economical management in innovative management. Some that have been identified in the research include "Openness in Information Sources", "Use of In-Hotel Information Sources", "R\&D Expenditures / Support for Innovation", "Presenting an Innovative Vision", "Spreading Innovative Management to All Units", "New Innovative Management Approaches", "Fundraising and Tasks Allocation", "Cooperation with Other Establishments and Market Size", "Participation in Decisions and Number of Solutions", and "Training and Idea Generation" (Tidd et al., 2001; Feams et al., 2005; Lukas \& Ferrell, 2000; De Jong \& Hartog 2010; Burmaoğlu \& Şenen, 2011). The purpose of this study was to determine the success criteria for innovative management and to find out the best hotel among the hotels that have a corporate identity in the city of Giresun, Turkey. The study examines the effect of the success criteria on the key components of competitive strength, business performance, and 
Evaluation of innovative management success criteria in hotel establishments: Case study...

timesaving. Due to the complex structure of the problem, Multi-criteria decisionmaking (MCDM) methods such as MOOSRA and EDAS are selected.

In the second part of the study, a literature review related to innovative management studies is presented. MOOSRA and EDAS methods used in the study are explained in the third part. A case study is analyzed in the fourth part, and the conclusion and suggestions are presented in the last part.

\section{Literature Review}

Numerous academic studies have been conducted on innovation and innovative management across different sectors and businesses. The sectors and types of businesses considered include government institutions and information infrastructure (Hendrick, 1994; Young et al., 2001; Sadriev \& Pratchenko, 2014, etc.), accounting systems (Chenhall \& Langfield-Smith, 1999), military systems (Drezner et al., 1999), universities and different educational institutions (Khoury \& Analoui, 2004; Zhao \& Ordóñez de Pablos, 2009; Barnard \& Van der Merwe, 2016), supply chains and distribution systems (Soosay \& Sloan, 2005; Majercak et al., 2016) and travel companies and the tourism sector (Buhalis \& O'Connor, 2005; Bolgova et al., 2016; Chkalova et al., 2019).

Hendrick (1994), who investigates the design, development, and implementation of information systems, states that information systems are very important for the success of innovative management approaches at all levels of governments. Young et al. (2001), who investigated the effects of top management and network in the adoption of innovative management practices in Total Quality Management (TQM) in public hospitals, determined that institution factors were important determinants. Sadriev \& Pratchenko (2014) examined the prerequisites of idea management systems in innovative management and analyzed modern management practices of different companies. They stated that production technologies need software support, evaluation, and the support of innovative ideas. Chenhall \& Langfield-Smith (1999) review innovations in management accounting systems (MAS) in manufacturing firms operating in Australia. They suggest that a commitment to the initiatives; a successful pilot application; incremental development; appropriate training; and integration with other processes and systems. Drezner et al. (1999) examine innovative management in unmanned aerial vehicle programs related to military and defense systems and explain innovative management in terms of military systems. Khoury \& Analoui (2004) set up an integrated and innovative model (SOFIA) to manage the performance evaluation process of full-time faculty members at Palestinian public universities. They addressed a variety of topics including setting of clear institutional strategy, participation in goal setting, coaching, two-way communication between faculty members and their superiors, feedback, developing and rewarding faculty members. Zhao \& Ordóñez de Pablos (2009) looked at innovative management within an organizational learning model by analyzing innovative management as a school subject and the impact of organizational learning. They find that education plays an important role in promoting innovative power and encourages creative education. Barnard \& Van der Merwe (2015) examined the role of innovative management in institutional sustainability in higher education. They found that innovation in sustainable development is supported by decisive leadership on strategic direction, regular, flexible, and inclusive planning, regular culture climate surveys, constant monitoring of progress, and strategic agility that is essential to promote innovation among the entire workforce. Soosay \& Sloan (2005), looking at the innovative 
management approach in distribution centers, found that resistance to change is inevitable, individuals express resistance both secretly and explicitly, and a cycle of resistance and acceptance against an emotional change should be expected and actively managed. They also stated that employee involvement is an essential component for successful change management. In supply chains, Majercak et al. (2016) stress the need to focus on innovation based on the position of the product life cycle.

The literature on innovative management in the tourism and travel sector seem to have almost similar results. Buhalis \& O'Connor (2005) addressed the changes in the tourism industry regarding Information Communication Technologies (ICT). They state that e-tourism and the Internet have greatly improved the process of developing, managing, and marketing tourism products and destinations, and have led to the emergence of new opportunities and new challenges. They contend that only organizations that appreciate the opportunities offered by the advancement in these areas and that can successfully bring and manage their ICT resources will be able to increase their innovation and competitiveness in the future. Bolgova et al. (2016), who examined the innovative management in travel companies, stated that the search for innovative attitudes and management is very important for the transformation, change, and competitive advantage in the tourism sector. According to the study, it is the task of leaders to get the most out of the investment and innovative technologies used in the operations of travel agencies. Chkalova et al. (2019) looked at the effects and functioning of an innovative mechanism to manage local systems in the tourism and recreation sector with a theoretical justification in the Volga Federal District of Russia. They stated that innovative mechanisms are very important for the management of local tourism systems. Chkalova et al. (2019) concluded that the suitability of the development of a local innovative system is largely determined by the current situation in the Russian economy and the ever-increasing role of integration in innovative systems at regional and inter-regional levels.

Delanoy \& Kasztelnik (2020) studied the supporting role of innovative leadership and management decisions in Canada. They argue that integrating innovative management processes such as demographic analysis, platform understanding, and communication methods are very important for any public businesses. They also state that in the age of social media, understanding innovative management and how consumers use open big data analytics resources will also help leadership practices. Based on expert opinions on the management of innovative processes in agriculture and food safety they obtained, Tokhayeva et al. (2020) emphasize that it is very important to encourage technological and innovative management practices regarding basic agriculture and food security, to encourage scientific development, and to contribute to information flows.

In a study investigating the innovative management of green tourism and recreational agriculture, Tao et al. (2021) argue that the development of leisure agriculture in the future will be based on experience, tourism, landscapes, and local cultures to highlight agricultural diversity, and therefore innovative management is important. Zaika et al. (2020), who investigated the development of innovative management methods in a modern business environment, state that distinguished techniques emphasized by specific tools ensure the consistent application of innovative management at all levels of the information business environment. They also emphasized that it is very important to study and implement more innovative mechanisms and impact tools on the current economic processes in tourism. This study derives its unique value from the fact that in the literature review, no study was found that examines the success criteria for innovative management and which ranks 
Evaluation of innovative management success criteria in hotel establishments: Case study...

the hotels based on the determined criteria. It is also differentiated by methodology utilized as well as used and the field of application hence provides a substantial contribution to the literature.

\section{Case Study}

In the study, a two-stage multi-criteria decision-making model was created to determine the success criteria for innovative management in hotel establishments and to evaluate the alternatives in the selection of the best hotel.

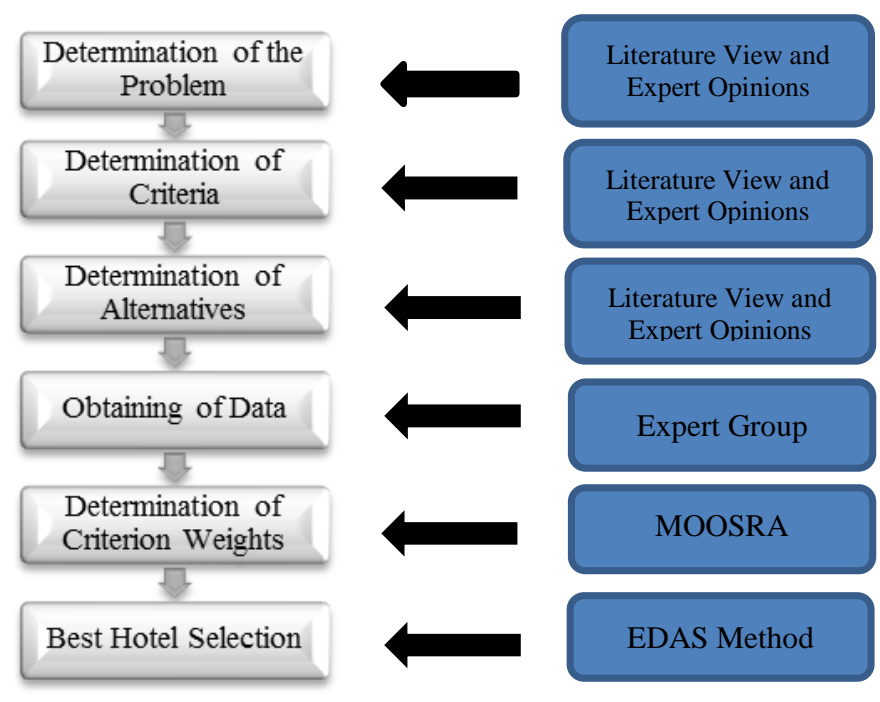

Figure 1. Application Steps of the Study

The processes in the study followed the order in the application steps shown in Figure 1. First, success criteria for innovative management in hotels were determined using the literature review and expert opinions and supported by the decision model. Since the criteria determined do not have the same level of importance, the criteria needed to be prioritized. This was achieved using the MOOSRA method. Based on the prioritized criteria, the selection for the best hotel based on the success criteria for the innovative management was done using the EDAS method.

To determine the criteria, opinions were sought from a total of 13 experts: managers from hotels with three stars and above operating in Giresun (10), officials from the Directorate of Culture and Tourism (1), and academicians working in the field of Tourism Management at Giresun University (2). The data were collected in January 2020, just before the decision to stop some services of hotels due to the Coronavirus (COVID-19). Table 1 was created based on the studies (Lukas \& Ferrell, 2000; Tidd et al., 2001; De Jong \& Hartog, 2010; Burmaoğlu \& Şeșen, 2011; Çapraz et al., 2014) in the related literature. 
Table 1. Decision Criteria

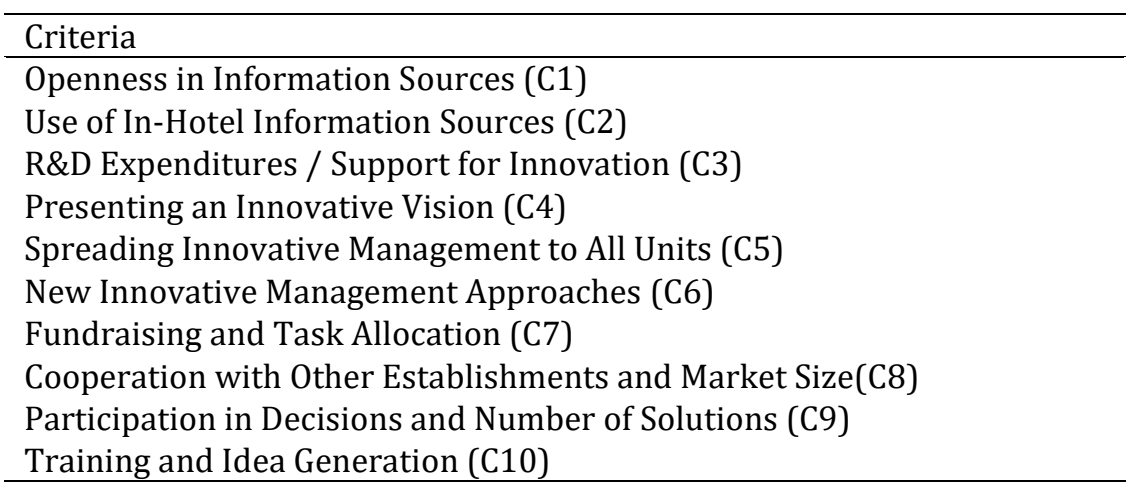

\section{Methodology}

The methodology section consists of two sections. The first section includes MOOSRA as a criteria-weighting method while the second section comprises EDAS as an approach for ranking alternatives.

\subsection{MOOSRA (Multi-Objective Optimization by Simple Ratio Analysis)}

The MOOSRA method, developed by Das et al. (2012), is one of the multi-purposes and optimization methods characterized by criteria, alternatives, or attributes of importance or individual weights (Jagadish and Ray, 2014). While, calculating the performance values of each alternative under the MOOSRA method, the normalized performance values of the useful and non-useful criteria are obtained by the simple ratio method (Baležentienè et al., 2013). The MOOSRA method has been used in several areas such as machine selection (Sarkar et al., 2015), project critical path selection (Dorfeshan et al., 2018), waste disposal assessment (Narayanamoorthy, 2020), laptop selection (Adalı \& Ișık, 2017), assessment of the quality of life (Ömürbek et al. 2017) and optimization of EDM process parameters (Anitha \& Das, 2020). The steps of the MOOSRA method are as follows (Jagadish \& Ray, 2014):

Step I. Creating the Decision Matrix: In this method, the process starts with the creation of a decision matrix seen as Table 2 listing the alternatives and criteria, and the performance of the relevant criterion or alternative is created as in Equation (1) below:

$X_{i j}=\left[\begin{array}{cccc}X_{11} & X_{12} & \cdots & X_{1 n} \\ X_{21} & X_{22} & \cdots & X_{2 n} \\ X_{m 1} & X_{m 2} & \cdots & X_{m n}\end{array}\right]$ 
Evaluation of innovative management success criteria in hotel establishments: Case study...

Table 2. Decision Matrix for MOOSRA

\begin{tabular}{ccccccccccc}
\hline Criteria & $\mathrm{C}_{1}$ & $\mathrm{C}_{2}$ & $\mathrm{C}_{3}$ & $\mathrm{C}_{4}$ & $\mathrm{C}_{5}$ & $\mathrm{C}_{6}$ & $\mathrm{C}_{7}$ & $\mathrm{C}_{8}$ & $\mathrm{C}_{9}$ & $\mathrm{C}_{10}$ \\
\hline $\mathrm{C}_{1}$ & 7 & 9 & 3 & 5 & 7 & 7 & 7 & 7 & 5 & 7 \\
$\mathrm{C}_{2}$ & 5 & 7 & 3 & 5 & 5 & 7 & 3 & 7 & 3 & 3 \\
$\mathrm{C}_{3}$ & 7 & 5 & 9 & 7 & 7 & 9 & 5 & 5 & 3 & 5 \\
$\mathrm{C}_{4}$ & 3 & 3 & 7 & 9 & 9 & 7 & 7 & 5 & 3 & 5 \\
$\mathrm{C}_{5}$ & 3 & 5 & 5 & 7 & 3 & 5 & 7 & 7 & 9 & 3 \\
$\mathrm{C}_{6}$ & 5 & 3 & 3 & 5 & 5 & 7 & 7 & 3 & 5 & 3 \\
$\mathrm{C}_{7}$ & 5 & 5 & 7 & 7 & 9 & 9 & 3 & 3 & 3 & 5 \\
$\mathrm{C}_{8}$ & 3 & 3 & 5 & 5 & 7 & 7 & 5 & 7 & 7 & 7 \\
$\mathrm{C}_{9}$ & 7 & 3 & 5 & 3 & 7 & 5 & 3 & 5 & 7 & 5 \\
$\mathrm{C}_{10}$ & 9 & 9 & 5 & 7 & 7 & 5 & 9 & 3 & 5 & 7 \\
\hline
\end{tabular}

Step II. Normalizing the Decision Matrix: The process of converting the attribute value to the 0-1 range is called normalization. In multi-criteria decision-making, the values in the decision matrix must be converted from different units to a uniform unit, and the normalization process is used for this purpose.

$X_{i j}^{*}=\frac{x_{i j}}{\sqrt{\sum_{i=1}^{n} x_{i j}^{2}}}$

The value $X_{i j}^{*}$ represents the normalized value of the $\mathrm{i}^{\text {th }}$ alternative over $\mathrm{j}^{\text {th }}$. Normalized decision matrix is seen as Table 3.

Table 3. Normalized Decision Matrix

\begin{tabular}{ccccccccccc}
\hline Criteria & $\mathrm{C}_{1}$ & $\mathrm{C}_{2}$ & $\mathrm{C}_{3}$ & $\mathrm{C}_{4}$ & $\mathrm{C}_{5}$ & $\mathrm{C}_{6}$ & $\mathrm{C}_{7}$ & $\mathrm{C}_{8}$ & $\mathrm{C}_{9}$ & $\mathrm{C}_{10}$ \\
\hline $\mathrm{C}_{1}$ & 0.385 & 0.502 & 0.172 & 0.255 & 0.324 & 0.319 & 0.372 & 0.406 & 0.294 & 0.423 \\
$\mathrm{C}_{2}$ & 0.275 & 0.390 & 0.172 & 0.255 & 0.232 & 0.319 & 0.159 & 0.406 & 0.176 & 0.181 \\
$\mathrm{C}_{3}$ & 0.385 & 0.279 & 0.515 & 0.356 & 0.324 & 0.410 & 0.266 & 0.290 & 0.176 & 0.302 \\
$\mathrm{C}_{4}$ & 0.165 & 0.167 & 0.400 & 0.510 & 0.417 & 0.319 & 0.372 & 0.290 & 0.176 & 0.302 \\
$\mathrm{C}_{5}$ & 0.165 & 0.279 & 0.286 & 0.356 & 0.139 & 0.228 & 0.372 & 0.406 & 0.528 & 0.181 \\
$\mathrm{C}_{6}$ & 0.275 & 0.167 & 0.172 & 0.255 & 0.232 & 0.319 & 0.372 & 0.174 & 0.294 & 0.181 \\
$\mathrm{C}_{7}$ & 0.275 & 0.279 & 0.400 & 0.356 & 0.417 & 0.410 & 0.159 & 0.174 & 0.176 & 0.302 \\
$\mathrm{C}_{8}$ & 0.165 & 0.167 & 0.286 & 0.255 & 0.324 & 0.319 & 0.266 & 0.406 & 0.411 & 0.423 \\
$\mathrm{C}_{9}$ & 0.385 & 0.167 & 0.286 & 0.153 & 0.324 & 0.228 & 0.159 & 0.290 & 0.411 & 0.302 \\
$\mathrm{C}_{10}$ & 0.495 & 0.502 & 0.286 & 0.356 & 0.324 & 0.228 & 0.478 & 0.174 & 0.294 & 0.423 \\
\hline
\end{tabular}

Step III. Defining Alternative Values: The performance values $\left(\mathrm{Y}_{\mathrm{i}}\right)$ of all alternatives are calculated by taking the simple ratio of the weighted sum of useful and non-useful criteria. In this calculation, the following Equation (3) is used.

$Y_{i}=\frac{\sum_{j=1}^{g} w_{j} x_{i j}^{*}}{\sum_{j=g+1}^{n} w_{j} x_{i j}^{*}}$

Step IV. Sorting Alternatives: In the last step, the alternatives are sorted. When alternatives are listed in descending order, the best alternative is the one with the highest value. Alternative values determination and sorting are formed as Table 4. 
$Y_{i}=\frac{\sum_{j=1}^{g} x_{i j}^{*}}{\sum_{j=g+1}^{n} x_{i j}^{*}}$

Table 4. Defining Alternative Values and Sorting

\begin{tabular}{lccc}
\hline Criteria & $\sum_{j=1}^{g} w j x_{i j}^{*}$ & $\sum_{j=g+1}^{n} w j x_{i j}^{*}$ & $Y_{i}$ \\
\hline $\mathrm{C}_{1}$ & 2.485 & 0.967 & 0.389 \\
$\mathrm{C}_{2}$ & 2.053 & 0.512 & 0.249 \\
$\mathrm{C}_{3}$ & 2.220 & 0.847 & 0.382 \\
$\mathrm{C}_{4}$ & 2.044 & 1.074 & 0.525 \\
$\mathrm{C}_{5}$ & 2.101 & 0.839 & 0.399 \\
$\mathrm{C}_{6}$ & 1.716 & 0.725 & 0.423 \\
$\mathrm{C}_{7}$ & 2.087 & 0.861 & 0.413 \\
$\mathrm{C}_{8}$ & 2.470 & 0.977 & 0.395 \\
$\mathrm{C}_{9}$ & 1.958 & 0.747 & 0.381 \\
$\mathrm{C}_{10}$ & 3.100 & 1.187 & 0.384 \\
\hline
\end{tabular}

\subsection{EDAS (Evaluation Based on Distance from Average Solution)}

EDAS is one of the Multiple Criteria Decision-Making methods introduced to the literature by Ghorabaee et al. (2015). EDAS Method uses evaluations based on average solution distance in determining the most optimal alternative in the decision-making process. The authors who developed the method compared the EDAS method with other Multiple Criteria Decision-Making (MCDC) methods such as VIKOR, TOPSIS, SAW, and COPRAS (Complex Proportional Assessment) and tested the validity of the method (Özbek \& Engür, 2018). EDAS has been used in several application areas such as information technology (Stanujkić et al., 2018), textile (Karabasević et al., 2018), transportation (Vesković et al., 2020), hospital selection (Gündoğdu et al., 2018), and supplier selection (Ghorabaee et al. 2016). The steps followed in the EDAS method are as follows (Ghorabaee et al., 2015).

Step I. Creating the Decision-Making Matrix (X): Decision-Making matrix is shown in Equation (5) below. In the corresponding matrix, $x_{i j}$; $i$ represents the performance of the option based on criteria $j$. Decision matrix for EDAS is seen as Table 5.

$X=X_{i j}=\left[\begin{array}{cccc}a_{11} & a_{12} & \cdots & a_{1 n} \\ a_{21} & a_{22} & \cdots & a_{2 n} \\ \vdots & \vdots & \ddots & \vdots \\ a_{m 1} & a_{m 2} & \cdots & a_{m n}\end{array}\right]$

Table 5. Decision Matrix for EDAS

\begin{tabular}{ccccccccccc}
\hline Alternatives & $\mathrm{C}_{1}$ & $\mathrm{C}_{2}$ & $\mathrm{C}_{3}$ & $\mathrm{C}_{4}$ & $\mathrm{C}_{5}$ & $\mathrm{C}_{6}$ & $\mathrm{C}_{7}$ & $\mathrm{C}_{8}$ & $\mathrm{C}_{9}$ & $\mathrm{C}_{10}$ \\
\hline $\mathrm{A}_{1}$ & 3.70 & 4.20 & 3.40 & 3.30 & 4.40 & 4.10 & 4.05 & 3.10 & 3.15 & 3.25 \\
$\mathrm{~A}_{2}$ & 2.80 & 2.95 & 3.00 & 4.10 & 4.25 & 3.75 & 3.70 & 3.55 & 3.40 & 2.45 \\
$\mathrm{~A}_{3}$ & 4.15 & 4.00 & 3.70 & 3.60 & 3.15 & 2.45 & 2.30 & 2.15 & 2.20 & 2.75 \\
$\mathrm{~A}_{4}$ & 1.90 & 2.15 & 1.75 & 2.35 & 3.30 & 1.95 & 1.70 & 2.85 & 1.55 & 3.10 \\
\hline
\end{tabular}

Step II. Creating the Mean Values Matrix $\left(A V_{i j}\right)$ : In the second stage of the EDAS method, the average solutions matrix related to the evaluation criteria is determined with the help of Equation (6). Average values matrix is obtained as Table 6. 
Evaluation of innovative management success criteria in hotel establishments: Case study...

$A V_{j}=\frac{\sum_{i=1}^{n} x_{i j}}{n}$

Table 6. Average Values Matrix

\begin{tabular}{ccccccccccc}
\hline Alternatives & $\mathrm{C}_{1}$ & $\mathrm{C}_{2}$ & $\mathrm{C}_{3}$ & $\mathrm{C}_{4}$ & $\mathrm{C}_{5}$ & $\mathrm{C}_{6}$ & $\mathrm{C}_{7}$ & $\mathrm{C}_{8}$ & $\mathrm{C}_{9}$ & $\mathrm{C}_{10}$ \\
\hline $\mathrm{A}_{1}$ & 3.70 & 4.20 & 3.40 & 3.30 & 4.40 & 4.10 & 4.05 & 3.10 & 3.15 & 3.25 \\
$\mathrm{~A}_{2}$ & 2.80 & 2.95 & 3.00 & 4.10 & 4.25 & 3.75 & 3.70 & 3.55 & 3.40 & 2.45 \\
$\mathrm{~A}_{3}$ & 4.15 & 4.00 & 3.70 & 3.60 & 3.15 & 2.45 & 2.30 & 2.15 & 2.20 & 2.75 \\
$\mathrm{~A}_{4}$ & 1.90 & 2.15 & 1.75 & 2.35 & 3.30 & 1.95 & 1.70 & 2.85 & 1.55 & 3.10 \\
\hline $\begin{array}{c}\text { Average } \\
\text { Value }\end{array}$ & 3.14 & 3.30 & 2.96 & 3.34 & 3.38 & 3.06 & 2.94 & 2.91 & 2.58 & 2.89 \\
\hline
\end{tabular}

Step III. Creating Positive and Negative Distance Matrices from Average: A positive distance from average ( $P D A)$ matrix and negative distance from average $(N D A)$ matrix are created for each criterion. The calculation of these values varies according to the benefit or cost characteristics of the criteria.

$\begin{aligned} P D A & =\left[P D A_{i j}\right]_{n x m} \\ N D A & =\left[N D A_{i j}\right]_{n x m}\end{aligned}$

In the equations given above, PDA refers to the positive distance of the $i^{\text {th }}$ alternative to the average solution of $j^{\text {th }}$ criteria, and NDA refers to the negative distance of the $i^{\text {th }}$ alternative to the average solution of $j^{\text {th }}$ criteria. If the evaluation criterion is benefit-oriented, Equations (9) and (10) are used.

$P D A_{i j}=\frac{\max \left(0,\left(X_{i j}-A V_{j}\right)\right.}{A V_{j}}, j \in$ benefit value

$N D A_{i j}=\frac{\max \left(0,\left(A V_{j}-X_{i j}\right)\right.}{A V_{j}}, j \in$ benefit value

If the evaluation criterion is cost-oriented, Equations (11) and (12) are used.

$P D A_{i j}=\frac{\max \left(0,\left(A V_{j}-X_{i j}\right)\right.}{A V_{j}}, j \in$ cost value

$N D A_{i j}=\frac{\max \left(0,\left(X_{i j}-A V_{j}\right)\right.}{A V_{j}}, j \in$ cost value

Average positive distance matrix and average negative distance matrix are formed as Table 7 and 8 respectively.

Table 7. Average Positive Distance Matrix

\begin{tabular}{ccccccccccc}
\hline Alternatives & $\mathrm{C}_{1}$ & $\mathrm{C}_{2}$ & $\mathrm{C}_{3}$ & $\mathrm{C}_{4}$ & $\mathrm{C}_{5}$ & $\mathrm{C}_{6}$ & $\mathrm{C}_{7}$ & $\mathrm{C}_{8}$ & $\mathrm{C}_{9}$ & $\mathrm{C}_{10}$ \\
\hline $\mathrm{A}_{1}$ & 0.178 & 0.273 & 0.149 & 0 & 0.302 & 0.340 & 0.378 & 0.065 & 0.221 & 0.125 \\
$\mathrm{~A}_{2}$ & 0 & 0 & 0.014 & 0.228 & 0.258 & 0.226 & 0.259 & 0.220 & 0.318 & 0 \\
$\mathrm{~A}_{3}$ & 0.322 & 0.212 & 0.250 & 0.078 & 0 & 0 & 0 & 0 & 0 & 0 \\
$\mathrm{~A}_{4}$ & 0 & 0 & 0 & 0 & 0 & 0 & 0 & 0 & 0 & 0.073 \\
\hline
\end{tabular}


Table 8. Average Negative Distance Matrix

\begin{tabular}{ccccccccccc}
\hline $\begin{array}{c}\text { Alterna- } \\
\text { tives }\end{array}$ & $\mathrm{C}_{1}$ & $\mathrm{C}_{2}$ & $\mathrm{C}_{3}$ & $\mathrm{C}_{4}$ & $\mathrm{C}_{5}$ & $\mathrm{C}_{6}$ & $\mathrm{C}_{7}$ & $\mathrm{C}_{8}$ & $\mathrm{C}_{9}$ & $\mathrm{C}_{10}$ \\
\hline $\mathrm{A}_{1}$ & 0 & 0 & 0 & 0.012 & 0 & 0 & 0 & 0 & 0 & 0 \\
$\mathrm{~A}_{2}$ & 0.118 & 0.106 & 0 & 0 & 0 & 0 & 0 & 0 & 0 & 0.152 \\
$\mathrm{~A}_{3}$ & 0 & 0 & 0 & 0 & 0.068 & 0.199 & 0.218 & 0.261 & 0.173 & 0.048 \\
$\mathrm{~A}_{4}$ & 0.395 & 0.349 & 0.409 & 0.296 & 0.023 & 0.363 & 0.422 & 0.021 & 0.399 & 0 \\
\hline
\end{tabular}

Step IV. Calculating Weighted Total Values: Weighted total positive distances $\left(S P_{i}\right)$ and weighted total negative $\left(S N_{i}\right)$ distances are calculated using Equations (13) and (14). The $w_{j}$ value in the equations expresses the importance of each evaluation criterion.

$$
\begin{aligned}
& S P_{i}=\sum_{j=1}^{m} w_{j} x P D A_{i j} \\
& S N_{i}=\sum_{j=1}^{m} w_{j} x N D A_{i j}
\end{aligned}
$$

Whether alternatives are optimal or not varies depending on whether $S P_{i}$ and $S N_{i}$ values increase or decrease. Weighted total positive $S P_{i}$ and weighted total negative $S N_{i}$ values are calculated and seen as Table 9 and 10 respectively.

Table 9. Weighted Total Positive $\mathrm{SP}_{\mathrm{i}}$ Values

\begin{tabular}{ccccccccccc}
\hline $\begin{array}{c}\text { Alterna- } \\
\text { tives }\end{array}$ & $\mathrm{C}_{1}$ & $\mathrm{C}_{2}$ & $\mathrm{C}_{3}$ & $\mathrm{C}_{4}$ & $\mathrm{C}_{5}$ & $\mathrm{C}_{6}$ & $\mathrm{C}_{7}$ & $\mathrm{C}_{8}$ & $\mathrm{C}_{9}$ & $\mathrm{C}_{10}$ \\
\hline $\mathrm{A}_{1}$ & 0.069 & 0.068 & 0.057 & 0 & 0.121 & 0.144 & 0.156 & 0.026 & 0.084 & 0.048 \\
$\mathrm{~A}_{2}$ & 0 & 0 & 0.004 & 0.120 & 0.103 & 0.096 & 0.107 & 0.087 & 0.121 & 0 \\
$\mathrm{~A}_{3}$ & 0.125 & 0.053 & 0.096 & 0.041 & 0 & 0 & 0 & 0 & 0 & 0 \\
$\mathrm{~A}_{4}$ & 0 & 0 & 0 & 0 & 0 & 0 & 0 & 0 & 0 & 0.028 \\
\hline
\end{tabular}

Table 10. Weighted Total Negative $\mathrm{SN}_{\mathrm{i}}$ Values

\begin{tabular}{ccccccccccc}
\hline $\begin{array}{c}\text { Alterna- } \\
\text { tives }\end{array}$ & $\mathrm{C}_{1}$ & $\mathrm{C}_{2}$ & $\mathrm{C}_{3}$ & $\mathrm{C}_{4}$ & $\mathrm{C}_{5}$ & $\mathrm{C}_{6}$ & $\mathrm{C}_{7}$ & $\mathrm{C}_{8}$ & $\mathrm{C}_{9}$ & $\mathrm{C}_{10}$ \\
\hline $\mathrm{A}_{1}$ & 0 & 0 & 0 & 0.006 & 0 & 0 & 0 & 0 & 0 & 0 \\
$\mathrm{~A}_{2}$ & 0.046 & 0.026 & 0 & 0 & 0 & 0 & 0 & 0 & 0 & 0.058 \\
$\mathrm{~A}_{3}$ & 0 & 0 & 0 & 0 & 0.027 & 0.084 & 0.090 & 0.103 & 0.066 & 0.018 \\
$\mathrm{~A}_{4}$ & 0.154 & 0.087 & 0.156 & 0.155 & 0.009 & 0.154 & 0.174 & 0.008 & 0.152 & 0 \\
\hline
\end{tabular}

Step V. Normalizing Weighted Total Distances: In step 5, the weighted and normalized $N S P_{i}$ and $N S N_{i}$ values of all alternatives are calculated with the help of Equations (15) and (16).

$$
\begin{aligned}
N S P_{i} & =\frac{S P_{i}}{\max _{i}\left(S P_{i}\right)} \\
N S N_{i} & =1-\frac{S N_{i}}{\max _{i}\left(S N_{i}\right)}
\end{aligned}
$$

$\mathrm{SP}_{\mathrm{i}}$ and $\mathrm{SP}_{\mathrm{i}}^{\mathrm{n}}$ values are computed for alternatives and seen as Table 11. 
Evaluation of innovative management success criteria in hotel establishments: Case study...

Table 11. $S P_{i}$ and $S P_{i}{ }^{n}$ Values

\begin{tabular}{ccc}
\hline Alternatives & $S P i$ & $S P i^{\mathrm{n}}$ \\
\hline $\mathrm{A}_{1}$ & 0.773 & 1 \\
$\mathrm{~A}_{2}$ & 0.638 & 0.825 \\
$\mathrm{~A}_{3}$ & 0.315 & 0.407 \\
$\mathrm{~A}_{4}$ & 0.028 & 0.036 \\
\hline
\end{tabular}

$\mathrm{SN}_{\mathrm{i}}$ and $\mathrm{SN}_{\mathrm{i}}{ }^{\mathrm{n}}$ values are calculated for alternatives and seen as Table 12.

Table 12. $\mathrm{SN}_{\mathrm{i}}$ and $\mathrm{SN}_{\mathrm{i}}^{\mathrm{n}}$ Values

\begin{tabular}{ccc}
\hline Alternatives & $\mathrm{SNi}$ & $\mathrm{SN}_{\mathrm{i}}^{\mathrm{n}}$ \\
\hline $\mathrm{A}_{1}$ & 0.006 & 0.994 \\
$\mathrm{~A}_{2}$ & 0.130 & 0.876 \\
$\mathrm{~A}_{3}$ & 0.388 & 0.630 \\
$\mathrm{~A}_{4}$ & 1.049 & 0 \\
\hline
\end{tabular}

Step VI. Calculating Success Scores for Each Alternative: In the last stage of the EDAS Method, $A S_{i}$, which represents the success score to be used in performance evaluation, is obtained for each alternative by taking the average of the $N S P_{i}$ and $N S N_{i}$ values calculated in the previous stage. Here, the alternative with the highest $A S_{i}$ value is considered the best alternative (Akbulut, 2019).

$A S_{i}=\frac{1}{2}\left(N S P_{i}+N S N_{i}\right)$

Evaluation scores and $\mathrm{AS}_{\mathrm{i}}$ values are calculated and alternative ranking is obtained as Table 13.

Table 13. Evaluation Scores and $\mathrm{AS}_{\mathrm{i}}$ Values

\begin{tabular}{ccc}
\hline Alternatives & $A S i$ & Ranking \\
\hline $\mathrm{A}_{1}$ & 0.977 & 1 \\
$\mathrm{~A}_{2}$ & 0.864 & 2 \\
$\mathrm{~A}_{3}$ & 0.519 & 3 \\
$\mathrm{~A}_{4}$ & 0.018 & 4 \\
\hline
\end{tabular}

\subsection{Weighting Criteria}

At this stage, using the MOOSRA method, a dual comparison questionnaire was created to evaluate the criteria. The questionnaire was presented to 13 experts, who are stakeholders of the subject area: hotel managers (10), Culture and Tourism Directorate officials (1), and academicians working in the field (2). The results of the analysis are presented below:

Table 14. Criteria Weights Table

\begin{tabular}{ccccccccccc}
\hline & $\mathrm{C}_{1}$ & $\mathrm{C}_{2}$ & $\mathrm{C}_{3}$ & $\mathrm{C}_{4}$ & $\mathrm{C}_{5}$ & $\mathrm{C}_{6}$ & $\mathrm{C}_{7}$ & $\mathrm{C}_{8}$ & $\mathrm{C}_{9}$ & $\mathrm{C}_{10}$ \\
\hline Weight & 0.389 & 0.249 & 0.382 & 0.525 & 0.399 & 0.423 & 0.413 & 0.395 & 0.381 & 0.384 \\
Ranking & 6 & 10 & 8 & 1 & 4 & 2 & 3 & 5 & 9 & 7 \\
\hline
\end{tabular}


According to Table 14, the most important criterion for innovative management success criteria is "Presenting an Innovative Vision". This was followed by "New Innovative Management Approaches", "Fundraising and Task Allocation" and "Spreading Innovative Management to All Units", respectively. On the other hand, the "Use of In-Hotel Information Sources" criterion was found as the least important criterion. The bottom of the list was rounded by "Participation in Decisions and Number of Solutions", "R\&D Expenditures / Support for Innovation", "Training and Idea Generation", "Openness in Information Sources", and "Cooperation with Other Establishments and Market Size", respectively as the least important criteria.

\subsection{Ranking of Alternatives}

In determining the alternatives for the study, the opinions of the expert group were taken into consideration and four hotels with corporate identity were determined. For the determined alternatives, a 1-5 Likert scale questionnaire was administered to the entire expert group. EDAS method was used to list these four alternatives. Using the weights of the criteria determined using MOOSRA, the best hotel with regard to success criteria for the innovative management was selected using the EDAS method. The ranking values obtained by the EDAS method are presented in the following table:

Table 15. Ranking Values with EDAS Method

\begin{tabular}{ccccc}
\hline & $\mathrm{A}_{1}$ & $\mathrm{~A}_{2}$ & $\mathrm{~A}_{3}$ & $\mathrm{~A}_{4}$ \\
\hline Value & 0.977 & 0.864 & 0.519 & 0.018 \\
Ranking & 1 & 2 & 3 & 4 \\
\hline
\end{tabular}

According to Table 15, A1 was chosen as the best hotel in Giresun regarding success criteria for innovative management in hotel establishments. The overall ranking in the selection of the best hotel regarding the success criteria for innovative management was $\mathrm{A} 1>\mathrm{A} 2>\mathrm{A} 3>\mathrm{A} 4$.

\section{Sensitivity Analysis}

It is important to review the results of the model according to the demands of decision-makers and different conditions. An essential component of the review is the detection of alternative ranking sensitivity in terms of varying decision makers' judgments. For this study, a sensitivity analysis was done to present the alternative ranking according to the changes in criteria weight as per the judgments of the decision-makers (Korucuk, 2019). If this level of rationality is demanded from an individual decision-maker, then MCDM methods used as a support to rational decision making should also satisfy the condition (Pamučar et al., 2017)

Several scenarios are formed for examining the alternative rankings for sensitivity analysis. While the first scenario assigns equal criteria weights, others allow for the interchange of weights between criteria. The obtained criteria weights for six scenarios are given in the Appendix A The results for the alternative ranking of the six different scenarios are presented in Table 16. 
Evaluation of innovative management success criteria in hotel establishments: Case study...

Table 16. Sensitivity analysis results

\begin{tabular}{|c|c|c|c|c|}
\hline Alternatives & $\overline{A_{1}}$ & $\mathrm{~A}_{2}$ & $\mathrm{~A}_{3}$ & $\mathrm{~A}_{4}$ \\
\hline Ranking & 1 & 2 & 3 & 4 \\
\hline \multicolumn{5}{|c|}{ Scenario 1. Assigning equal weights to all criteria } \\
\hline Scenario ranking & 1 & 2 & 3 & 4 \\
\hline \multicolumn{5}{|c|}{$\begin{array}{c}\text { Scenario } 2 \text {. The interchange between criteria having the highest weight and the } \\
\text { lowest weight }\end{array}$} \\
\hline Scenario ranking & 1 & 2 & 3 & 4 \\
\hline \multicolumn{5}{|c|}{$\begin{array}{c}\text { Scenario 3. The interchange between criteria having the second-highest weight } \\
\text { and the second-lowest weight }\end{array}$} \\
\hline Scenario ranking & 1 & 2 & 3 & 4 \\
\hline \multicolumn{5}{|c|}{$\begin{array}{c}\text { Scenario } 4 . \text { The interchange between criteria having the third-highest weight and } \\
\text { the third lowest weight }\end{array}$} \\
\hline Scenario ranking & 1 & 2 & 3 & 4 \\
\hline \multicolumn{5}{|c|}{$\begin{array}{l}\text { Scenario 5. The interchange between criteria having the fourth highest weight } \\
\text { and the fourth-lowest weight }\end{array}$} \\
\hline Scenario ranking & 1 & 2 & 3 & 4 \\
\hline
\end{tabular}

The results of the sensitivity analysis show a similar alternative ranking for the six different scenarios, an indication of the strength of the study in terms of significance and validity.

\section{Conclusion and Suggestions}

The innovative management approach has been considered to be effective in the execution of other innovation activities. Therefore, the development of successful innovative management structures in organizations should be able to raise the performance levels of the organization and increase their productivity, while also positively impacting competitiveness. Effective innovative management also clears the path for other innovative elements such as product/service, customer satisfaction, marketing, and process. Successful innovative management ensures the satisfaction of internal and external customers and effective resource use. This is because successful management practices affect the competitiveness of a firm, its efficiency, customer satisfaction, the performance of its internal processes, and many more value-added factors. Due to the range of factors involved, the determination of the success criteria for innovative management and the selection of the best hotel is considered a complex decision-making problem, and thus, the determination of the most suitable one among the alternatives requires the use of MCDM methods.

The main purpose of this study was to determine the success criteria for innovative management and to select the best hotel in line with the established criteria. This process was performed using MOOSRA and EDAS methods.

The results show that the most important criterion for the determination of success criteria for innovative management in hotels was "Presenting an Innovative Vision (C4)". This was followed, respectively, by "New Innovative Management Approaches (C6)", "Fundraising and Task Allocation (C7)" and, "Spreading Innovative Management to All Units (C5)", respectively. The other end of the spectrum had "Use of In-Hotel Information Sources (C2)" as the least important criterion. This was followed by "Participation in Decisions and Number of Solutions (C9)", "R\&D Expenditures / Support for Innovation (C3)", "Training and Idea Generation (C10)", "Openness in 
Information Sources (C1)", and "Cooperation with Other Establishments and Market Size (C8)", in that order.

A1 was found to be the best hotel in Giresun based on the success criteria for innovative management in hotel establishments outlined in this study. The overall ranking of the alternatives was $\mathrm{A} 1>\mathrm{A} 2>\mathrm{A} 3>\mathrm{A} 4$.

With the effect of globalization, production approaches and management in the organizations have shown radical changes as mentioned in the previous sections of this study. As has been stated in the various news articles regarding the current pandemic (Covid-19), things in organizations are not going to go back to where they were. For this reason, establishments, operating in the service sector, such as hotels, should be very careful in this regard. This is because, for the hotel industry, most of the tourism activities are produced and consumed by people, and often require faceto-face relationships. With the opening of the hotels, the study recommends that the hotels should approach their production and management innovatively in the new order. Establishments should adopt more human-oriented innovative management styles, and ensure that their employees are satisfied.

To the best of our knowledge, the extant literature doesn't have any similar studies. The methodology used and the area of application (hotels in the Turkish province of Giresun) give the study its originality edge.

The application, on hotel businesses, of the numerous criteria compiled from the literature regarding the success criteria of innovative management can be considered as the basic limitation of this study.

One of the limitations of the study was the smaller number of the expert group interviewed. The number could not be increased due to time constraints. Another limitation of the study is that no similar criterion sets on the innovative management theme was found in both the opinions of the expert group and the literature review.

The Covid-19 pandemic could be cited as another factor that limited the study. Due to the epidemic, the number of expert groups could not be increased. It is important to note that the results obtained with MOOSRA and EDAS methods may change with the differentiation of experts. In future studies, these deficiencies could be eliminated by including the opinions of all relevant stakeholders and evaluating them using different MCDM methods.

Despite the limitations, it was determined, in the interviews with the expert group, that the results of the study supported the expectations of the decision-makers. However, modeling the real situation is both very difficult and complex because human decisions, expectations, and judgments cannot be expressed precisely in numerical terms and are ambiguous. In addition, the findings of the study only relate to businesses operating in the hotel sector. Future studies may expand this by considering different sectors as well as use different Multi-Criteria Decision-Making methods in the selection and ranking.

On the other hand, future studies could also look at how the success criteria for innovative management relate to each other, determine the nature of this relationship using appropriate MCDM and compare the results obtained with the results of the present study.

Comparisons could also be done using fuzzy and/or extensions-based MCDM methods.

Author Contributions: Each author has participated and contributed sufficiently to take public responsibility for appropriate portions of the content.

Funding: This research received no external funding. 
Evaluation of innovative management success criteria in hotel establishments: Case study...

Conflicts of Interest: The authors declare no conflicts of interest.

\section{References}

Adalı, E.A. \& Işık, A.T. (2017). The multi-objective decision making methods based on MULTIMOORA and MOOSRA for the laptop selection problem. Journal of Industrial Engineering International, 13, 229-237.

Akbulut, O. Y. (2019). CRITIC ve EDAS yöntemleri ile İş Bankası'nın 2009-2018 yılları arasındaki performansının analizi. Journal of Research in Economics Politics and Finance, 4(2), 249-263.

Anitha J. \& Das R. (2020). Optimization of EDM Process Parameters Using Standard Deviation and Multi-objective Optimization on the Basis of Simple Ratio Analysis (MOOSRA). In Reddy A., Marla D., Simic M., Favorskaya M., \& Satapathy S. (Eds.), Intelligent Manufacturing and Energy Sustainability. Smart Innovation, Systems and Technologies, 169. Singapore: Springer.

Baležentienė, L., Štreimikienė, D., \& Baležentis, T. (2013). Fuzzy decision support methodology for sustainable energy crop selection. Renewable and Sustainable Energy Reviews, 17, 83-93.

Baporikar, N. (2015). Innovation knowledge management nexus. In Machado, C., \& Davim, J. P. (Eds.), Innovation Management, In Research and Industry (pp. 85-110). Berlin: De Gruyter.

Barnard, Z. \& Van der Merwe, D. (2016). Innovative management for organizational sustainability in higher education. International Journal of Sustainability in Higher Education, 17(2), 208-227.

Bayhan, B. D. (2004). Teknoloji ve inovasyon yönetimi. In Kiper, M. (Ed.), Teknoloji, (pp. 283-308). Ankara: Kozan Ofset.

Berghman, L., Matthyssens, P., Streukens, S., \& Vandenbempt, K. (2013). Deliberate Learning Mechanisms for Stimulating Strategic Innovation Capacity. Long Range Planning, 46, 39-71.

Bolgova, V. V., Makushkin, S. A., Povorina, E. V., Duplij, E. V., \& Demchenko, T. S. (2016). The innovative control management of travel companies. International Review of Management and Marketing, 6(6), 79-84.

Bolton, R. N., Grewal, D., \& Levy, M. (2007). Six strategies for competing through service: an agenda for future research. Journal of Retailing, 83(1), 1-4.

Buhalis, D., \& O'Connor, P. (2005). Information communication technology revolutionizing tourism. Tourism Recreation Research, 30(3), 7-16.

Burmaoğlu, S., \& Şeşen, H. (2011). Türk firmalarının organizasyonel inovasyon yeteneğini etkileyen faktörler üzerine bir araştırma. Ankara University SBF Journal, 66(4), 1-20.

Çapraz, B., Ünnü, N. A. A., İliç, K. D., Kocamaz, M., Çiçekli, G. U., Aracıoğlu, B., Koçak, A., Kesken, J., \& Soyuer, H. (2014). Çalışanlar perspektifinden inovatif iş davranışının belirleyicileri: İzmir ilindeki öncelikli sektörlere ilişkin bir araștırma. Journal of Entrepreneurship and Innovation Management, 3(1), 49-72. 
Chenhall, R. H., \& Langfield-Smith, K. (1999). The implementation of innovative management accounting systems. Australian Accounting Review, 9(19), 37-46.

Chkalova, O., Efremova, M., Lezhnin, V., Polukhina, A., \& Sheresheva, M. (2019). Innovative mechanism for local tourism system management: a case study. Entrepreneurship and Sustainability Issues, 6(4), 2052-2067.

Das, M. C., Sarkar, B., \& Ray, S. (2012). Comparative evaluation of Indian technical institutions using fuzzy AHP and MOORA. International Journal of Multicriteria Decision Making, 2(1), 74-93.

De Jong J., \& Hartog, D.D. (2010). Measuring innovative work behaviour. Creativity and Innovation Management, 19(1), 23-36.

Delanoy, N., \& Kasztelnik, K. (2020). Business Open Big Data Analytics to Support Innovative Leadership Decision in Canada. Business Ethics and Leadership, 4(2), 5674.

Dorfeshan, Y., Mousavi, S.M., Mohagheghi, V., \& Vahdani, B. (2018). Selecting projectcritical path by a new interval type-2 fuzzy decision methodology based on MULTIMOORA, MOOSRA and TPOP methods. Computers \& Industrial Engineering, 120, 160-178.

Drezner, J. A., Sommer, G., \& Leonard, R. S. (1999). Innovative management in the DARPA high altitude endurance unmanned aerial vehicle program. Washington: RAND National Defense Research Institute.

Drucker, P.F. (2003). Yenilikçilik İçerisinde Yenilikçilik Disiplini. (Çev: Ahmet Kardam). İstanbul: MESS Yayınları.

Elçi, Ş. (2007). İnovasyon: kalkınma ve rekabetin anahtarı. (2 $2^{\text {nd }}$ ed.). İstanbul: Türkiye Bilişim Derneği.

Faems, D., Van Looy, B., \& Debackere, K. (2005). Interorganizational collaboration and innovation: toward a portfolio approach. Journal of Product Innovation Management, 22(3), 238-250.

Fischer, S. (2003). Globazation and its challenges. American Economic Review, 93(2), 1-30.

Ghorabaee, M. K., Zavadskas, E. K., Amiri, M., \& Turskis, Z. (2016). Extended EDAS Method for Fuzzy Multi-criteria Decision-making: An Application to Supplier Selection. International journal of computers communications \& control, 11(3), 358-371.

Ghorabaee, M. K., Zavadskas, E. K., Olfat, L., \& Turskis, Z. (2015). Multi-criteria inventory classification using a new method of evaluation based on distance from average solution (EDAS). Informatica, 26(3), 435-451.

Gündoğdu, F. K., Kahraman, C., \& Civan, H. N. (2018). A Novel Hesitant Fuzzy EDAS Method and Its Application to Hospital Selection. Journal of Intelligent \& Fuzzy Systems, 35(6), 6353 - 6365.

Hamel, G. (2007). Eşik atlayan şirketlerin sırrı yönetim inovasyonunda. Capital, 15(5), 9-13.

Hamel, G., \& Bren, B. (2007). The future of management, Harvard Business Review Press, Canada. 
Evaluation of innovative management success criteria in hotel establishments: Case study...

Hendrick, R. (1994). An information infrastructure for innovative management of government. Public Administration Review, 54(6), 543-550.

Jagadish, J. \& Ray, A. (2014). Green cutting fluid selection using MOOSRA method. International Journal of Research in Engineering and Technology, 3(3), 559-563.

Karabasević, D., Maksimović, M., Stanujkić, D., Brzaković, P., \& Brzaković, M. (2018). The evaluation of websites in the textile industry by applying ISO/IEC 9126-4 standard and the EDAS method. Industria Textila, 69(6), 489-494.

Khoury, G. C., \& Analoui, F. (2004). Innovative management model for performance appraisal: the case of the Palestinian public universities. Management Research News, $27(1 / 2), 56-73$.

Korucuk, S. (2019). Üretim İșletmelerinde Verimliliğin Önündeki Engellerin ve Verim Arttırıcı Tekniklerin Bütünleşik AHP-TOPSIS İle Sıralanması: Erzurum İli Örneği, Verimlilik Dergisi. Sayı, 1, 219-241.

Lukas, B. A., \& Ferrell, O. C. (2000). The effect of market orientation on product innovation. Journal of the Academy of Marketing Science, 28(2), 239-247.

Majercak, J., Kudlac, S., \& Ponicky, J. (2016). Innovative management of supply chains. Logi-Scientific Journal on Transport and Logistics, 7(1), 98-107.

Memiş, S., \& Korucuk, S. (2019). Dematel ve Vikor Bütünleşik Yaklaşımı ile gıda işletmelerinde inovasyon çeşitlerinin önceliklendirilmesi ve en ideal firma seçimi. MANAS Journal of Social Studies, 8(1/2), 1099-1113.

Narayanamoorthy, S., Annapoorani, V., Kang, D., Baleanu, D., Jeon, J., Kureethara, J.V., \& Ramya, L. (2020). A novel assessment of bio-medical waste disposal methods using integrating weighting approach and hesitant fuzzy MOOSRA. Journal of Cleaner Production, 275, 1-16.

Ömürbek, N., Eren, H., \& Dağ, O. (2017). ENTROPİ-ARAS ve ENTROPİ-MOOSRA Yöntemleri İle Yaşam Kalitesi Açısından AB Ülkelerinin Değerlendirilmesi. Ömer Halisdemir Üniversitesi İktisadi ve İdari Bilimler Fakültesi Dergisi, 10(2), 29-48.

Özbek, A., \& Engür, M. (2018). EDAS yöntemi ile lojistik firma web sitelerinin değerlendirilmesi. Journal of Selçuk University Social Sciences Vocational School, 21, (2), 417-429.

Pamučar, D., Božanić, D., Ranđelović, A. (2017). Multi-criteria decision making: An example of sensitivity analysis. Serbian Journal of Management, 12(1), 1-27.

Sadriev, A. R., \& Pratchenko, O.V. (2014). Idea management in the system of innovative management. Mediterranean Journal of Social Sciences, 5(12), 155-158.

Sarkar, A., Panja, S.C., Das, D. \& Sarkar, B. (2015). Developing an efficient decision support system for non-traditional machine selection: an application of MOORA and MOOSRA. Production \& Manufacturing Research, 3(1), 324-342.

Smith, M., Busi, M., Ball, P., \& Van der Meer, R. (2008). Factors influencing an organisation's ability to manage innovation: a structured literature review and conceptual model. International Journal of Innovation Management, 12(4), 655-676.

Soosay, C. A., \& Sloan, T. R. (2005). Driving change: innovative management in distribution centres. Journal of Asia Entrepreneurship and Sustainability, 1(2), 1-21. 
Soylu, A., \& Göl, Ö.M. (2010). Yönetim inovasyonu. Sosyoekonomi, 6(11), 113-130.

Stanujkić, D., Popović, G., \& Brzaković, M. (2018). An approach to personnel selection in the IT industry based on the EDAS method. Transformations in Business \& Economics, 17(2), 54-65.

Subramaniam, M., \& Youndt, M. A. (2005). The influence of intellectual capital on the types of innovative capabilities. Academy of Management Journal, 48(3), 450-463.

Tao, Y. H., Wang, R. Y., Ling, H. C., Chu, J. Y., \& Ji, H. (2021). Implementing for Innovative Management of Green Tourism and Leisure Agriculture in Taiwan. International Journal of Organizational Innovation, 13(3), 210-219.

Tether, B. S. (2005). Do services innovate (differently)? Insights from the European innobarometer survey. Industry \& Innovation, 12(2), 153-184.

Tidd J., Bessant, J., \& Pavitt, K. (2001). Managing innovation integrating technological, market, and organizational change. ( $2^{\text {nd }}$ ed.). New York: John Wiley \& Sons.

Tiftik, C. (2020). Inovasyon Yönetiminin İşletme Performansına Etkisi. IBAD Sosyal Bilimler Dergisi , (Özel Sayı), 180-201.

Tokhayeva, Z.O., Almukhambetova, B.Z., Keneshbayev, B., \& Akhmetova, K. (2020). Innovative Processes' Management in Agriculture and Food Security: Development Opportunities. Entrepreneurship and Sustainability Issues, 7(3), 1565-1579.

Tucker, A., Edmondson, A., \& Spear, S. (2002). When problem solving prevents organizational learning. Journal of Organizational Change Management, 15(2), 122137.

Vesković, S., Stević, Ž., Karabašević, D., Rajilić, S., Milinković, S., \& Stojić, G. (2020). A New Integrated Fuzzy Approach to Selecting the Best Solution for Business Balance of Passenger Rail Operator: Fuzzy PIPRECIA-Fuzzy EDAS Model. Symmetry, 12(5), 743.

Young, G. J., Charns, M. P., \& Shortell, S. M. (2001). Top manager and network effects on the adoption of innovative management practices: a study of TQM in a public hospital system. Strategic Management Journal, 22, 935-951.

Zaika, Y.A, Gaman, P. I., Gaman, N. O., Solomko, A. S., \& Chukaeva, I. K. (2020). Innovative Management Methods in Terms of the Information Business Environment at the Enterprise. International Journal of Management (IJM), 11(3), 529-542.

Zhao, J., \& Ordóñez de Pablos, P. (2009). School innovative management model and strategies: the perspective of organizational learning. Information Systems Management, 26(3), 241-251. 
Evaluation of innovative management success criteria in hotel establishments: Case study...

\section{Appendix A}

Table A1. Scenario 1 alternative ranking

\begin{tabular}{|c|c|c|c|c|c|c|c|c|c|}
\hline \multirow{2}{*}{ Weight } & \multirow{2}{*}{$\begin{array}{c}\mathrm{C}_{1} \\
0.1\end{array}$} & \multirow{2}{*}{$\begin{array}{c}\mathrm{C}_{2} \\
0.1\end{array}$} & \multirow{2}{*}{$\begin{array}{c}\mathrm{C}_{3} \\
0.1\end{array}$} & \multirow{2}{*}{$\begin{array}{c}\mathrm{C}_{4} \\
0.1\end{array}$} & \multirow{2}{*}{$\mathrm{C}_{5}$} & $\mathrm{C}_{6}$ & $\mathrm{C}_{8}$ & $\mathrm{C}_{9}$ & \multirow{2}{*}{$\begin{array}{l}\mathrm{C}_{10} \\
0.1\end{array}$} \\
\hline & & & & & & 0.1 & 0.1 & 0.1 & \\
\hline & & & & $\mathrm{A}_{1}$ & $\mathrm{~A}_{2}$ & $\mathrm{~A}_{3}$ & $\mathrm{~A}_{4}$ & & \\
\hline & & $\mathrm{Va}$ & & 0.998 & 0.819 & 0.447 & 0.096 & & \\
\hline & & Ran & & 1 & 2 & 3 & 4 & & \\
\hline
\end{tabular}

Table A2. Scenario 2 alternative ranking

\begin{tabular}{|c|c|c|c|c|c|c|c|c|}
\hline & $\mathrm{C}_{1}$ & $\mathrm{C}_{2}$ & $\mathrm{C}_{3}$ & $\mathrm{C}_{4}$ & $\mathrm{C}_{5}$ & $\mathrm{C}_{6}$ & $\mathrm{C}_{7}$ & $\mathrm{C}_{8}$ \\
\hline \multirow{4}{*}{ Weight } & 0.389 & 0.525 & 0.382 & 0.249 & 0.399 & 0.423 & 0.413 & 30.395 \\
\hline & & & & $\mathrm{A}_{1}$ & $\mathrm{~A}_{2}$ & & 3 & $\mathrm{~A}_{4}$ \\
\hline & & $\mathrm{Val}$ & & 0.999 & 0.768 & & 26 & 0.017 \\
\hline & & Ran & & 1 & 2 & & 3 & 4 \\
\hline
\end{tabular}

Table A3. Scenario 3 alternative ranking

\begin{tabular}{ccccccccccc}
\hline & $\mathrm{C}_{1}$ & $\mathrm{C}_{2}$ & $\mathrm{C}_{3}$ & $\mathrm{C}_{4}$ & $\mathrm{C}_{5}$ & $\mathrm{C}_{6}$ & $\mathrm{C}_{7}$ & $\mathrm{C}_{8}$ & $\mathrm{C}_{9}$ & $\mathrm{C}_{10}$ \\
\hline Weight & 0.389 & 0.249 & 0.382 & 0.525 & 0.399 & 0.381 & 0.413 & 0.395 & 0.423 & 0.384 \\
\hline
\end{tabular}

\begin{tabular}{ccccc}
\hline & $\mathrm{A}_{1}$ & $\mathrm{~A}_{2}$ & $\mathrm{~A}_{3}$ & $\mathrm{~A}_{4}$ \\
\hline Value & 0.997 & 0.856 & 0.522 & 0.018 \\
Ranking & 1 & 2 & 3 & 4 \\
\hline
\end{tabular}

Table A4. Scenario 4 alternative ranking

\begin{tabular}{|c|c|c|c|c|c|c|c|c|c|c|}
\hline & $\mathrm{C}_{1}$ & $\mathrm{C}_{2}$ & $\mathrm{C}_{3}$ & $\mathrm{C}_{4}$ & $\mathrm{C}_{5}$ & $\mathrm{C}_{6}$ & $\mathrm{C}_{7}$ & $\mathrm{C}_{8}$ & $\mathrm{C}_{9}$ & $\mathrm{C}_{10}$ \\
\hline \multirow[t]{4}{*}{ Weight } & 0.389 & 0.249 & 0.413 & 0.525 & 0.399 & 0.423 & 0.382 & 0.395 & 0.381 & 0.384 \\
\hline & & & & $\mathrm{A}_{1}$ & $\mathrm{~A}_{2}$ & & $\mathrm{~A}_{3}$ & $\mathrm{~A}_{4}$ & & \\
\hline & & & & 0.997 & 0.851 & & .524 & 0.019 & & \\
\hline & & Ran & king & 1 & 2 & & 3 & 4 & & \\
\hline
\end{tabular}

Table A5. Scenario 5 alternative ranking

\begin{tabular}{ccccccccccc}
\hline & $\mathrm{C}_{1}$ & $\mathrm{C}_{2}$ & $\mathrm{C}_{3}$ & $\mathrm{C}_{4}$ & $\mathrm{C}_{5}$ & $\mathrm{C}_{6}$ & $\mathrm{C}_{7}$ & $\mathrm{C}_{8}$ & $\mathrm{C}_{9}$ & $\mathrm{C}_{10}$ \\
\hline Weight & 0.389 & 0.249 & 0.382 & 0.525 & 0.384 & 0.423 & 0.413 & 0.395 & 0.381 & 0.399 \\
\hline
\end{tabular}

\begin{tabular}{ccccc}
\hline & $\mathrm{A}_{1}$ & $\mathrm{~A}_{2}$ & $\mathrm{~A}_{3}$ & $\mathrm{~A}_{4}$ \\
\hline Value & 0.997 & 0.848 & 0.520 & 0.019 \\
Ranking & 1 & 2 & 3 & 4 \\
\hline
\end{tabular}


Demirdag et al./Decis. Mak. Appl. Manag. Eng. 4 (2) (2021) 26-46

Table A6. Scenario 6 alternative ranking

\begin{tabular}{|c|c|c|c|c|c|c|c|c|c|c|}
\hline & $\mathrm{C}_{1}$ & $\mathrm{C}_{2}$ & $\mathrm{C}_{3}$ & $\mathrm{C}_{4}$ & $\mathrm{C}_{5}$ & $\mathrm{C}_{6}$ & $\mathrm{C}_{7}$ & $\mathrm{C}_{8}$ & $\mathrm{C}_{9}$ & $\mathrm{C}_{10}$ \\
\hline \multirow[t]{4}{*}{ Weight } & 0.395 & 0.249 & 0.382 & 0.525 & 0.399 & 0.423 & 0.413 & 0.389 & 0.381 & 0.384 \\
\hline & & & & $\mathrm{A}_{1}$ & $\mathrm{~A}_{2}$ & & $\mathrm{~A}_{3}$ & $\mathrm{~A}_{4}$ & & \\
\hline & & & lue & 0.997 & 0.756 & & .412 & 0.018 & & \\
\hline & & Rar & king & 1 & 2 & & 3 & 4 & & \\
\hline
\end{tabular}

(C) 2018 by the authors. Submitted for possible open access publication under the terms and conditions of the Creative Commons Attribution (CC BY) license (http://creativecommons.org/licenses/by/4.0/). 